\title{
Projections of water futures for Australia: an update
}

\author{
H. Zheng ${ }^{1}$, F.H.S. Chiew ${ }^{1}$, N.J. Potter ${ }^{1}$ and D.G.C. Kirono ${ }^{2}$ \\ ${ }^{1}$ CSIRO Land and Water, Canberra \\ ${ }^{2}$ CSIRO Oceans and Atmosphere, Melbourne \\ Email: hongxing.zheng@csiro.au
}

\begin{abstract}
This paper presents projections of hydrological metrics for Australia under a future climate, from modelling carried out in the Earth Systems and Climate Change Hub. These projections are modelled using three rainfall-runoff models informed by future climate projections from 42 CMIP GCMs used in IPCC AR5. The runoff projections are the same as those presented in Chiew et al. (2017). The paper also presents projections of hydrological metrics beyond just the long-term averages that are important for many applications. The paper presents and discusses the implications of different data treatments used to obtain future climate series to drive hydrological models, modelling with different hydrological models, and limitations and challenges in modelling climate change impact on hydrology. Future runoff is likely to decline in far southwest and south-east Australia, but the range or uncertainty in the projections is large. Despite continuing progress in climate change and hydrological modelling sciences, the uncertainty in projections is likely to remain large. Planning water systems and outcomes for the future need to consider the range of plausible climate and water futures, and develop adaptation options that balance the cost of adaptation versus the risk from not adapting sufficiently and fast enough.
\end{abstract}

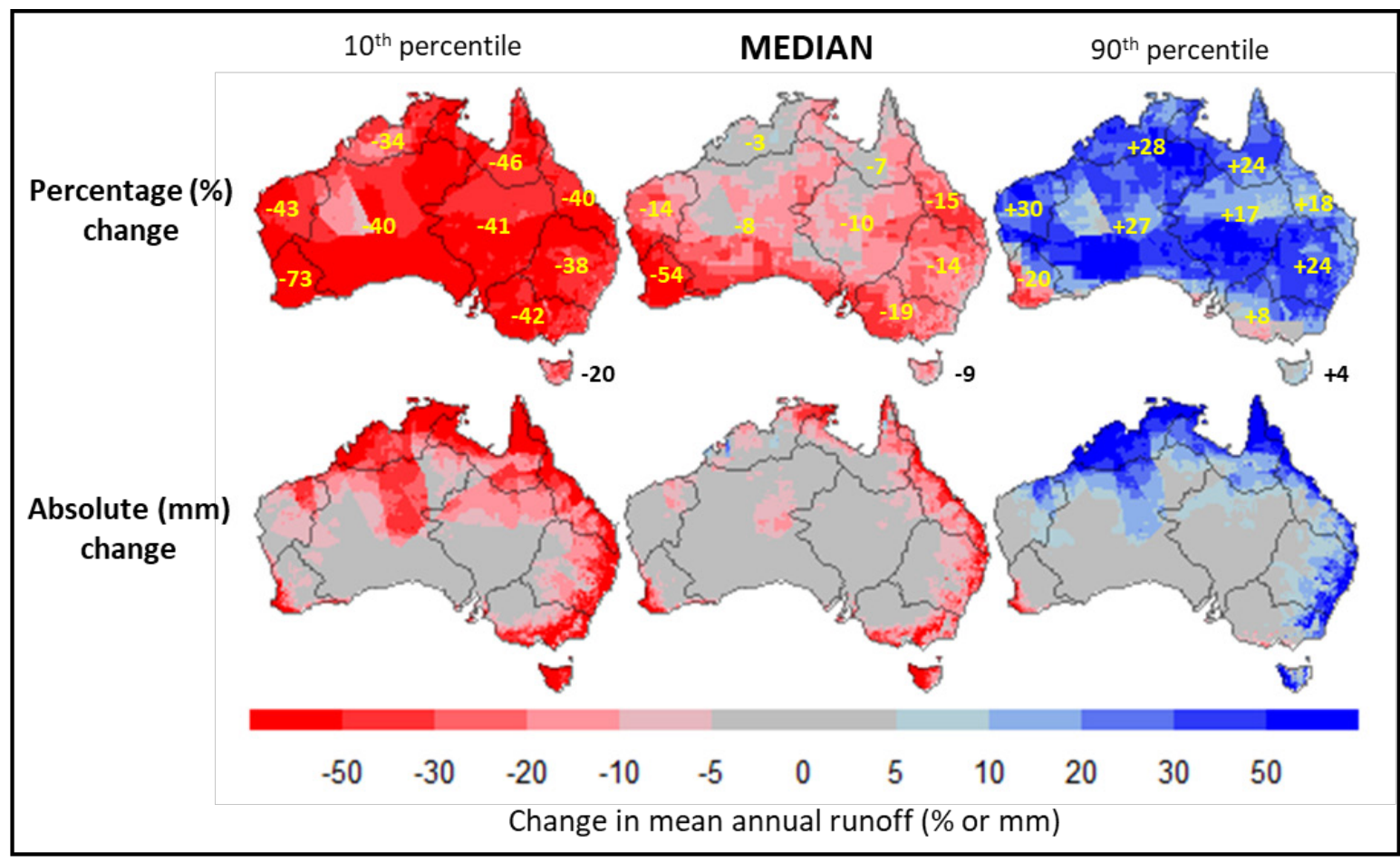

Figure 1. Projected change in mean annual runoff (median and the $10^{\text {th }}$ and $90^{\text {th }}$ percentile values from GR4J hydrological modelling informed by climate change projections from the 42 CMIP5 GCMs) for RCP8.5 for 2046-2075 relative to 1976-2005. The projections also reflect change in runoff for a $\sim 2.2^{\circ} \mathrm{C}$ global average warming relative to the 1986-2005 IPCC AR5 reference period. The large range in the projections mainly reflects the uncertainty in rainfall projections across the 42 CMIP5 GCMs.

Keywords: Climate change, runoff, projections, water futures, hydrological metrics, Australia 


\section{INTRODUCTION}

Robust projections of water futures are important to assess the impact and vulnerability of water and related systems, and to plan and assess adaptation options to mitigate climate change risk. The latest nationally consistent projections of climate futures for Australia were released in 2015 (CSIRO and Bureau of Meteorology, http://www.climatechangeinaustralia.gov.au). Severalh activities in the Earth Systems and Climate Change (ESCC) Hub of the National Environmental Science Programme are currently building the underpinning projections science and modelling capability required for the next generation national climate projections following the release of the Intergovernmental Panel on Climate Change (IPCC) Sixth Assessment Report in 2021.

This paper presents an update of projections of water futures from the modelling undertaken in the ESCC Hub. The paper presents the plausible range of projected changes in the long-term average runoff, as well as changes to hydrological metrics important for many applications (Ekstrom et al. 2018).

\section{MODELLING CLIMATE CHANGE IMPACT ON RUNOFF}

The modelling is similar to that described in Chiew et al. (2017), which has been improved upon and reproduced here. The historical and future runoffs are simulated using three conceptual rainfall-runoff models (GR4J, Perrin et al. 2003; SIMHYD, Chiew et al. 2002; and Xinanjiang, Zhao et al. 1992) for $0.05^{\circ}$ grid cells across Australia. The rainfall-runoff model is calibrated against observed streamflow data from more than 700 catchments across Australia. The NSE-Bias objective criteria (Chiew et al. 2018) is used, where the models are calibrated to best reproduce the observed daily streamflows, as well as with minimal bias in the total observed streamflow. Runoff for each grid cell is modelled using parameter values from the geographically nearest calibration catchment. Runoff is modelled for 1976-2005 (baseline period) using daily rainfall and PET as the input data. The source of the daily rainfall data is the SILO gridded dataset (Jeffrey et al. 2001). Potential evapotranspiration (PET) is calculated from the SILO climate surface using Morton's wet environment or areal PET algorithm (Chiew and McMahon 1991).

The future runoff is modelled using future rainfall and PET series obtained by empirically scaling the baseline (1976-2005) historical climate series informed by the change signal from global climate models (GCMs). There are three stages in the empirical scaling: the daily rainfall in each of the four seasons at the different rainfall percentiles are scaled by different factors (daily scaling, to reflect change in the daily rainfall distribution); the data is then rescaled such that the future rainfall reflects the GCM change signal at the seasonal level (seasonal scaling); the data is then rescaled again such that the future rainfall reflects the GCM change signal at the annual level (annual scaling).

The results presented here are for a change signal for 2046-2075 relative to 1976-2005 for RCP8.5. The RCP8.5 represents the highest representative greenhouse gas concentration pathway defined in IPCC AR5 (IPCC Fifth Assessment Report, IPCC 2014). The median warming in RCP8.5 is a $2.2^{\circ} \mathrm{C}$ increase in global average temperature by 2060 relative to 1986-2005 (IPCC, 2014). All ensemble runs from the 42 GCMs available on 15 March 2013 (the same date as adopted by IPCC AR5 and in the CSIRO and BoM 2015 projections) in the CMIP5 database (http://cmip-pcmdi.llnl.gov/cmip5/) are used. The GCMs in CMIP5 (Coupled Model Intercomparison Project) come from more than 30 modelling groups across the world.

\section{PROJECTIONS OF WATER FUTURES}

The plots in Figures 1 to 5 show the projected range of change in future rainfall and runoff. Projections are presented for mean annual runoff, different runoff percentiles and high and low flow characteristics. The $95^{\text {th }}$ percentile daily runoff $\left(\mathrm{Q}_{95}\right)$ (i.e. runoff that is exceeded on average 18 days every year) is arbitrarily used here to represent high flow condition which reflects high runoff, overbank discharge or floodplain connectivity. The $5^{\text {th }}$ percentile daily runoff $\left(\mathrm{Q}_{05}\right)$ is used here to represent low flow condition which reflects low flow threshold or environmental water for ecosystem function. The 7Q10 metric is the lowest 7-day flow that occurs on average once every 10 years, which is often used to reflect the frequency of ecosystem exposure to low flow.

The future rainfall projection plots in Figure 2 show that (i) winter rainfall is likely to decline across Australia, (ii) annual rainfall is likely decline in the winter-rainfall dominated southern Australia, and (iii) extreme high daily rainfall intensity will either increase, or decrease less compared to the average rainfall. As runoff 
generated during high rainfall contributes significantly to the total runoff, modelling with future rainfall from the daily rainfall scaling treatment (which considers different changes to the different parts of the daily rainfall distribution) results in more future runoff compared to using future rainfall from just the seasonal and annual scaling treatments (Figure 3).

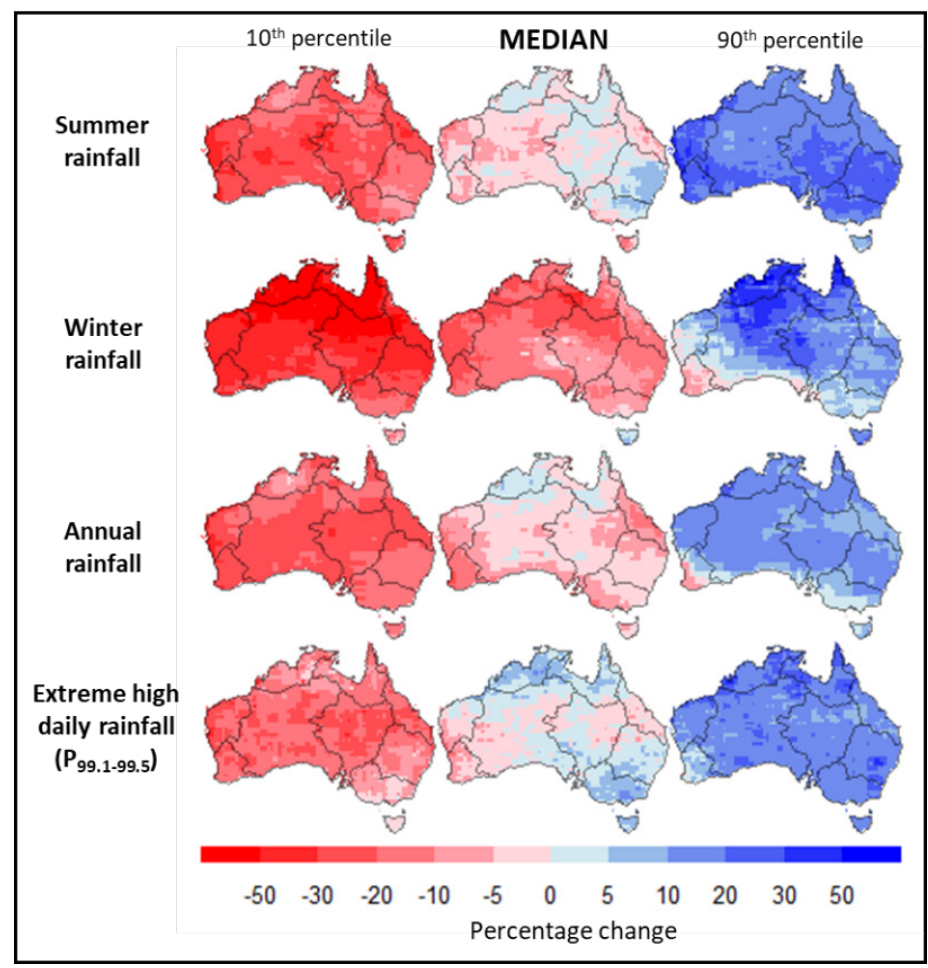

Figure 2. Projected change in mean summer, winter and annual rainfall, and extreme high daily rainfall ( $\mathrm{P}_{99.1-99.5}$, i.e. daily rainfall that is exceeded two or three days each year) (median and the $10^{\text {th }}$ and $90^{\text {th }}$ percentile values from the 42 CMIP5 GCMs) for RCP8.5 for 2046-2075 relative to 1976-2005.

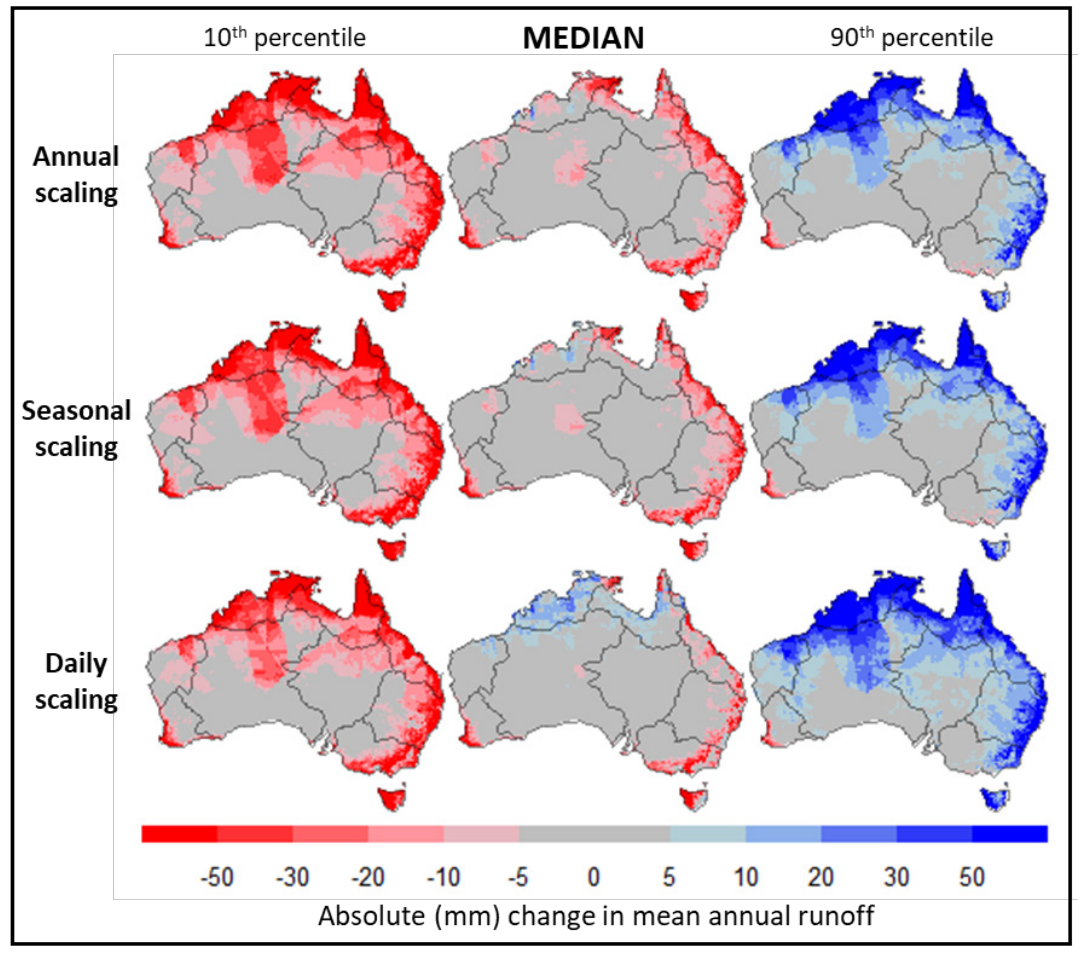

Figure 3. Projected change in mean annual runoff (median and the $10^{\text {th }}$ and $90^{\text {th }}$ percentile values from GR $4 \mathrm{~J}$ hydrological modelling informed by climate change projections from the 42 CMIP5 GCMs) for RCP8.5 for 2046-2075 relative to 1976-2005 for future climate input series obtained using the annual, seasonal and daily scaling methods. 
The projected change in rainfall, as well as the uncertainty or range in the rainfall projection, are amplified in the future runoff projection. The projected range of future runoff, modelled by the GR4J rainfall-runoff model using future rainfall series from empirical annual scaling treatment (to be consistent with Chiew et al. 2017) by 2046-2075 for RCP8.5, is shown in Figure 1. The median projection for northern Australia is about 5\% reduction in mean annual runoff, with a $10^{\text {th }}$ and $90^{\text {th }}$ percentile uncertainty range of $-40 \%$ to $+30 \%$. The median projection for eastern Australia is about $15 \%$ reduction in mean annual runoff with an uncertainty range of $-40 \%$ to $+20 \%$.

There is stronger agreement in the projections for declining runoff in southern Australia. Most of the runoff here occurs in winter, and the majority of GCMs project a drier future winter. The projection of declining winter rainfall is also supported by trends in the observations and explanation of change in the global circulation under warmer conditions causing a poleward shift in rainfall bearing weather systems in southern Australia (Hope et al. 2017, Post et al. 2014). In the far south-west, the median projection is a decline of mean annual runoff of $50 \%$ (with an extreme dry projection of $-70 \%$ ), and in the far south-east, the median projection is a decline of mean annual runoff of $20 \%$ (with an extreme dry projection of $-40 \%$ ) (Figure 1 ).

Figure 4 shows projected changes to the different runoff percentiles and Figure 5 shows projected changes to high flow and low flow characteristics. These are presented here to provide some indication on likely changes to river flow characteristics beyond the long-term average that impact various applications and domains like multi-year water storages and ecosystems. The change in the hydrological metrics follow the pattern of rainfall and runoff projection, that is, higher temperature and projected decline in rainfall (particularly in southern Australia) will result in more frequent and severe drought, lower multi-year storage reliability, reduced high flow, overbank discharge and floodplain inundation, and more time spent in low flows. It should be noted that the empirical scaling approach used here to obtain the future rainfall series do not take into account potential changes in rainfall characteristics that may influence these hydrological metrics, for example, multi-year low rainfall, and changes in daily rainfall sequencing. Nevertheless, knowledge about climate change impact on rainfall characteristics beyond the seasonal averages and extreme high rainfall (which are considered here) is still limited.

The plots in Figure 6 compare modelled runoff projections from three rainfall-runoff models. The modelled change in mean annual runoff, in response to changed climate inputs, between rainfall-runoff models is considerably smaller than the uncertainty in the future rainfall projections. This is also generally the case for the medium and high flow metrics. However, the modelled low flow projections differ significantly between the rainfall-runoff models (e.g. projected increase in low flow days is considerably greater in GR4J than the other two models). This is mainly because low flows are difficult to simulate, because low flows are difficult to define precisely, and because of the different model structures used to represent the low flow processes. The results presented throughout this paper are for model calibrations against NSE-Bias which reflects simulations of medium and high daily flows. Nevertheless, similar studies (e.g. Chiew et al. 2018) that calibrate the models directly against low flow objective criteria, also show considerable difficulty, and differences between rainfallrunoff models, in modelling low flows under current and future climates.

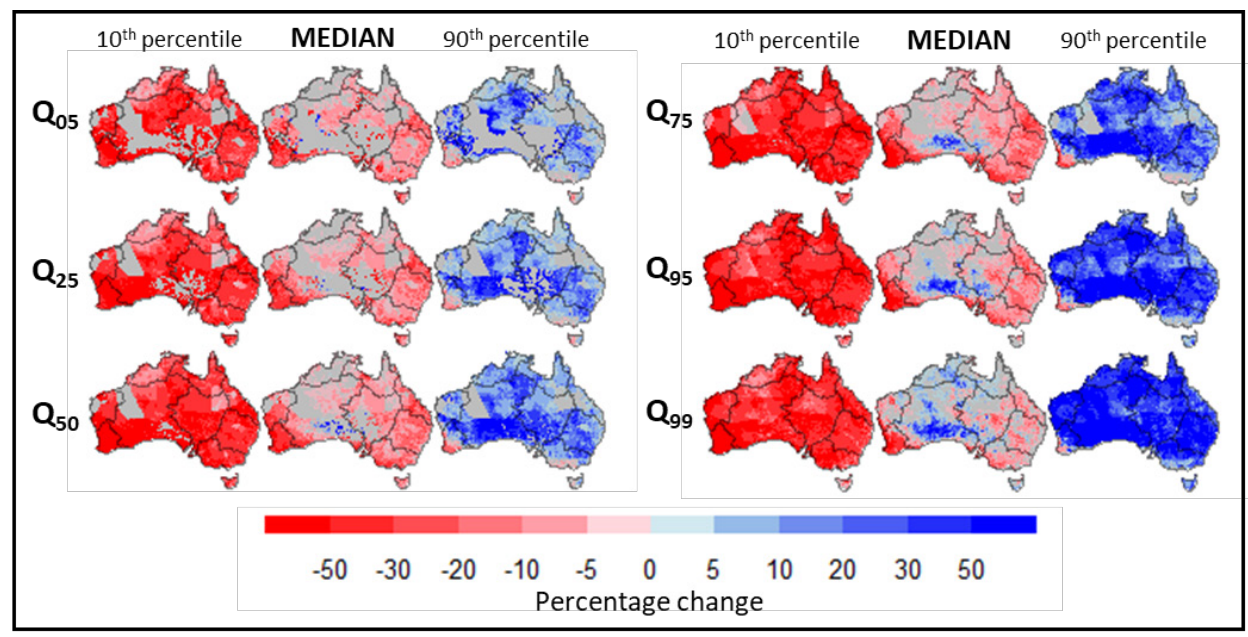

Figure 4. Projected change in daily runoff percentiles (median and the $10^{\text {th }}$ and $90^{\text {th }}$ percentile values from GR4J hydrological modelling informed by climate change projections from the 42 CMIP5 GCMs) for RCP8.5 for 2046-2075 relative to $1976-2005$. 


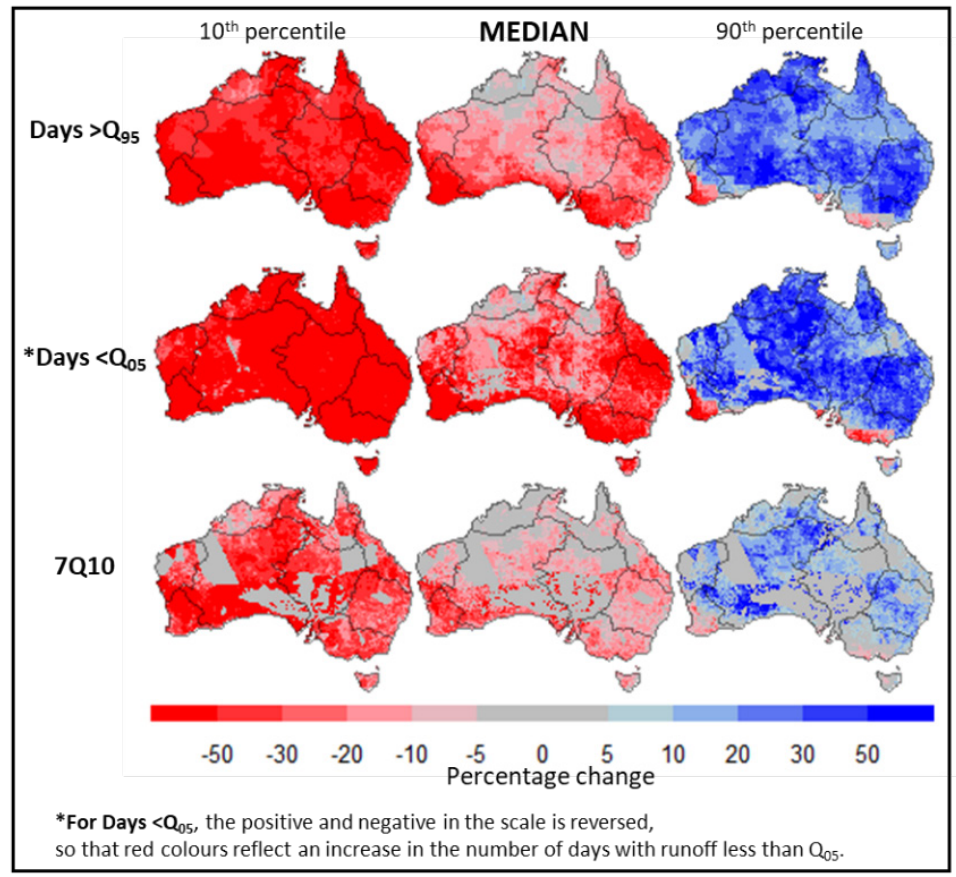

Figure 5. Projected change in high flow and low flow characteristics (median and the $10^{\text {th }}$ and $90^{\text {th }}$ percentile values from GR4J hydrological modelling informed by climate change projections from the 42 CMIP5 GCMs) for RCP8.5 for 20462075 relative to $1976-2005$.

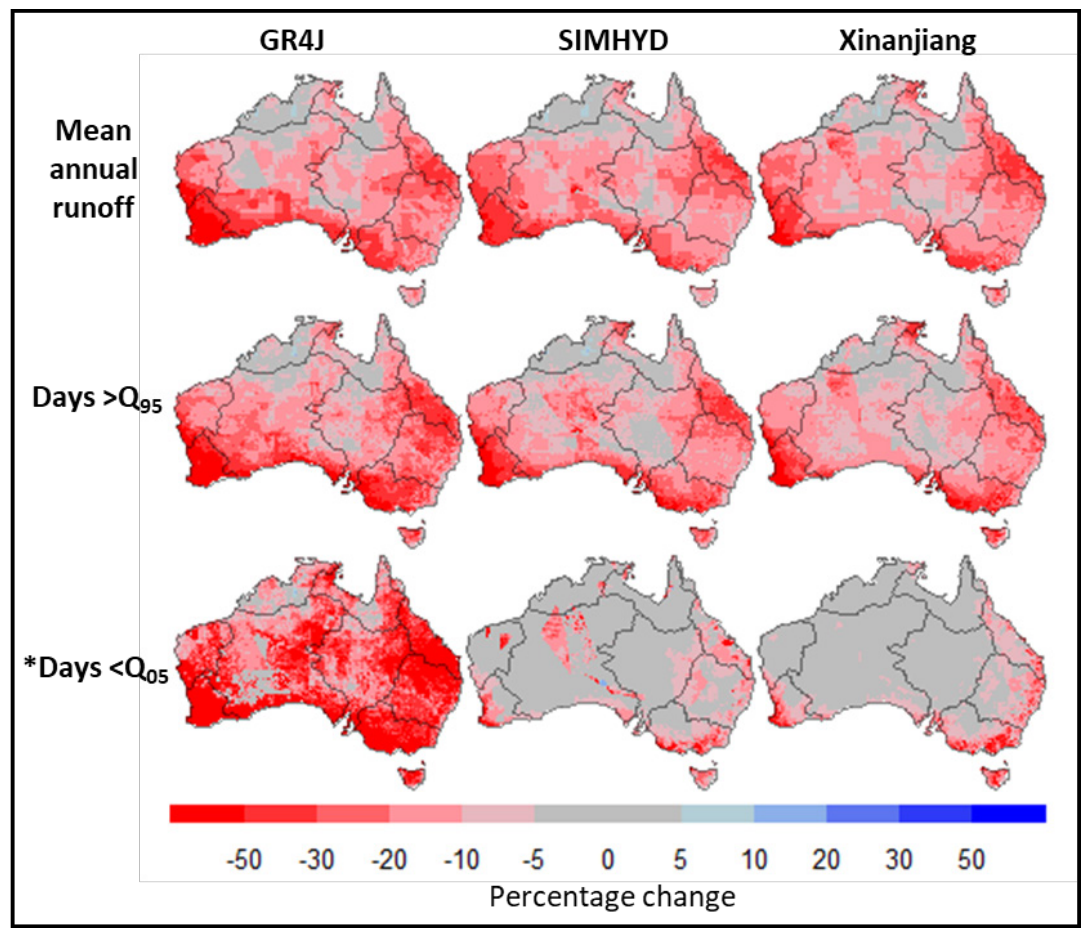

Figure 6. Median projected changes in runoff characteristics modelled by the three rainfall-runoff models.

\section{LIMITATIONS AND CHALLENGES}

The various uncertainties in knowledge and modelling climate change impact on water futures are shown in Figure 7 and discussed in detail in Chiew et al. (2017), and is briefly summarised here. The largest uncertainty is in the future rainfall projections. Excellent reviews of attempts to reduce the uncertainty in rainfall projections, and appraisals and guidance on selecting and interpreting climate projections data can be found in 
CSIRO and BoM (2015), Ekstrom et al. (2015, 2016) and Grose et al. (2015). The ESCC Hub is currently coordinating efforts on projections science and modelling capability for the next generation climate projections (NESP ESCC 2018).

For some parts of Australia, dynamic downscaling can improve the representation of regional climate features and extreme weather events. However, the added value of downscaling in providing future climate projections is difficult to evaluate because of limited dynamic downscaling modelling runs and sometimes considerable disagreement in the rainfall projections between downscaling models (Ekstrom et al. 2015). In addition, there is significant bias or error in the downscaled rainfall compared to the observed rainfall, and robustly biascorrecting the rainfall features important for hydrological modelling is challenging (Potter et al. 2019, Charles et al. 2019).

There is also significant uncertainty in extrapolating hydrological models developed against past observations to predict further into the future where hydrological fluxes and stores will be influenced not only by the changed climate input data, but increasingly by higher temperature, changed dominant hydrological processes (particularly evapotranspiration and surface-groundwater interaction) and changed ecohydrological processes under higher atmospheric $\mathrm{CO}_{2}$ not seen in the past (Chiew et al. 2014). Several studies have now shown that traditional application of hydrological models will underestimate the range in the future hydrological impact (Vaze et al. 2010, Saft et al. 2016, Fowler et al. 2016). However, understanding changed catchment and landscape conditions and then adapting hydrological models to represent them are complex challenges as identified as one of the 23 unsolved problems in hydrology by the International Association of Hydrological Sciences (Bloschl et al. 2019).

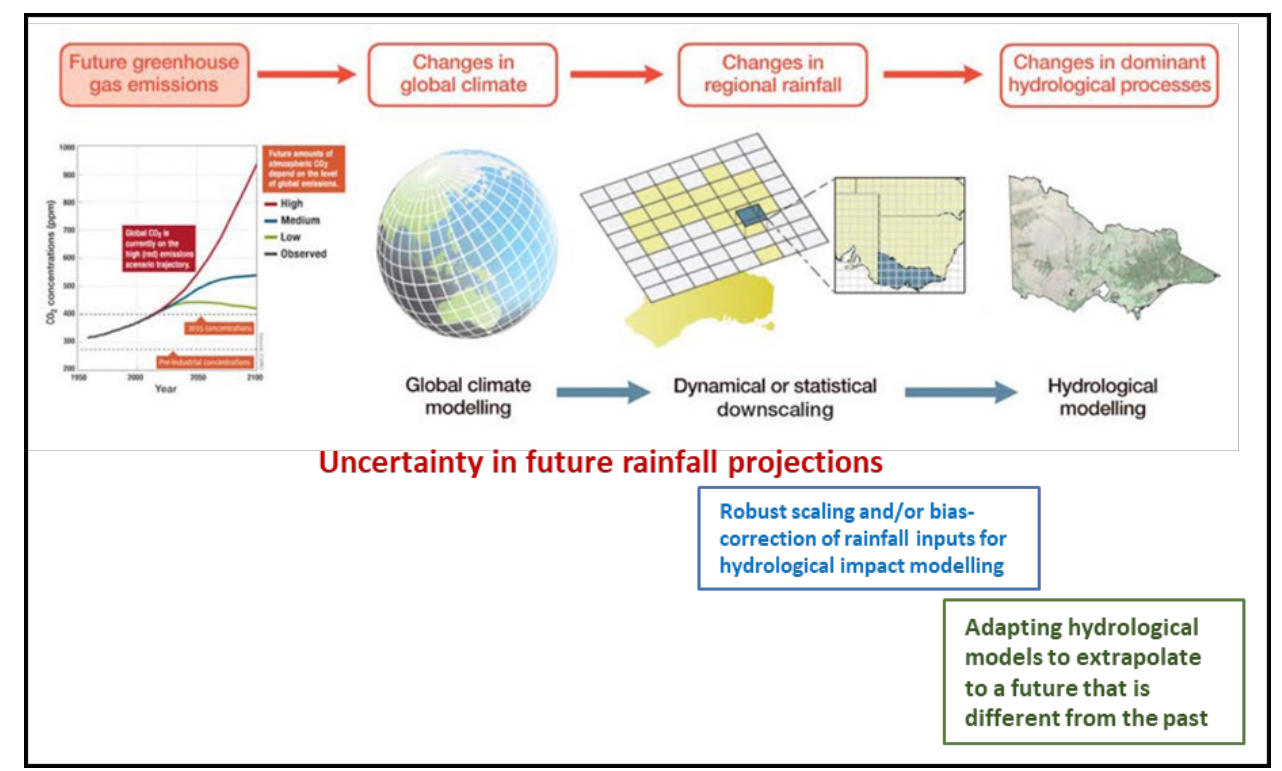

Figure 7. Modelling components and uncertainties in knowledge and modelling climate change impact on water futures

\section{SUMMARY AND CONCLUSIONS}

This paper presents projections of hydrological metrics under a future climate (mean seasonal rainfall, mean annual runoff, different runoff percentiles, high and low flow characteristics). These projections are modelled using three rainfall-runoff models informed by future climate projections from 42 CMIP5 GCMs. These projections complement the national climate projections for Australia's NRM regions. The paper also summarises the uncertainties in knowledge and modelling, and challenges in developing next generation climate and water projections.

Projections of climate and water futures will continue to improve with the rapid progress in climate change and hydrological science and modelling. However, limitations will remain, and future projections by definition will continue to be uncertain. Planning water systems and outcomes for the future need to consider the range of plausible climate and water futures, and develop adaptation options that balance the cost of adaptation versus the risk from not adapting sufficiently and fast enough. 


\section{ACKNOWLEDGEMENTS}

The modelling presented here is carried out in the Earth Systems and Climate Change Hub of the Australian Government's National Environmental Science Programme. The research is also supported by the Victorian Water and Climate Initiative and CSIRO strategic fund.

\section{REFERENCES}

Bloschl G, Bierkens MFP, Chambel A, Cudennec C, Destouni G, Fiori A, Kirchner JW, McDonnell JJ, Savenije HHG, Sivapalan M, Stumpp C, Toth E, Volpi E et al. (2019) Twenty-three unsolved problems in hydrology (UPH) - a community perspective. Hydrological Sciences Journal, http://dx.doi.org/10.1080/02626667.2019.1620507.

Charles SP, Chiew FHS, Potter NJ, Zheng H, Fu G and Zhang L (2019) Impact of dynamically downscaled rainfall biases on projected runoff changes. In Review.

Chiew FHS and McMahon TA (1991) The applicability of Morton's and Penman's evapotranspiration estimates in rainfall-runoff modelling. Water Resources Bulletin, 27, 611-620.

Chiew FHS, Peel MC and Western AW (2002) Application and testing of the simple rainfall-runoff model SIMHYD. In: Mathematical Models of Small Watershed Hydrology and Applications (Eds: VP Singh, DK Frevert), Water Resources Publication, Littleton Colorado, USA, pp. 335-367.

Chiew FHS, Potter NJ, Vaze J, Petheram C, Zhang L, Teng J and Post DA (2014) Observed hydrologic non-stationarity in far south-eastern Australia: implications and future modelling predictions. Stochastic Environmental Research and Risk Assessment, 28, 3-15.

Chiew FHS, Zheng H and Potter NJ (2018) Rainfall-runoff modelling considerations to predict streamflow characteristics in ungauged catchments and under climate change. Water, 1319, http://dx.doi.org/10.3390/w10101319.

Chiew FHS, Zheng H, Potter NJ, Ekstrom M, Grose R, Kirono DGC, Zhang L and Vaze J (2017) Future runoff projections for Australia and science challenges in producing next generation projections. MODSIM 2017, Hobart, Australia, Dec 2017, pp. 1745-1751.

CSIRO and Bureau of Meteorology (2015) Climate change in Australia information for Australia's natural resources management regions. Technical report, CSIRO and Bureau of Meteorology, https://www.climatechangeinaustralia.gov.au.

Ekstrom M, Guttman ED, Wilby RL, Tye MR and Kirono DGC (2018) Robustness of hydroclimate metrics for climate change impact research. WIREs Water, 5, https://onlinelibrary.wiley.com/doi/epdf/10.1002/wat2.1288.

Ekstrom M, Grose MR and Whetton PH (2015) An appraisal of downscaling methods used in climate change research. WIREs Climate Change, http://dx.doi.org/10.1002/wcc.339.

Ekstrom M, Grose M, Heady C, Turner S and Teng J (2016) The method of producing climate change datasets impacts the resulting policy guidance and chance of maladaptation. Climate Services, 4, 13-29.

Fowler KJ, Peel MC, Western AW, Zhang L and Peterson TJ (2016) Simulating runoff under changing climate conditions: revisiting an apparent deficiency of conceptual rainfall-runoff models. Water Resources Research, 3 , $1820-1846$.

Grose MR, Bhend J, Argueso D, Ekstrom M, Dowdy AJ, Hoffman P, Evans JP and Timbal B (2015) Comparison of various climate change projections of eastern Australian rainfall. Australian Meteorological and Oceanographic Journal, 65, 72-89.

Hope P, Timbal B, Hendon H, Ekstrom M and Potter N (2017) A synthesis of findings from the Victorian Climate Initiative. Australian Bureau of Meteorology, $56 \mathrm{pp}$, http://www.water.vic.gov.au/ data/assets/pdf file/0030/76197/VicCI-25-07-17-MR.pdf.

Intergovernmental Panel on Climate Change (2014) Climate change 2014: synthesis report. Contribution of working groups I, II and III to the Fifth Assessment Report of the IPCC, $151 \mathrm{pp}$, http://www.ipcc.ch/report/ar5/syr/.

Jeffrey SJ, Carter JO, Moodie KB and Beswick AR (2001) Using spatial interpolation to construct a comprehensive archive of Australian climate. Environmental Modelling and Software, 16, 309-300.

NESP ESCC (2018) NextGen climate change projections: Science ides and issues for national climate projections in Australia. Earth Systems and Climate Change Hub Report 5, http://nespclimate.com.au/wpcontent/uploads/2018/06/ESCC-R005-NextGen-projections-180629.pdf.

Perrin C, Michel C and Andreassian V (2003) Improvement of a parsimonious model for streamflow simulations. Journal of Hydrology, 279, 275-289.

Post DA, Timbal B, Chiew FHS, Hendon HH, Nguyen H and Moran R (2014) Decrease in southeastern Australian water availability linked to ongoing Hadley cell expansion. Earth's Future, 2, 231-238.

Potter NJ, Chiew FHS, Charles SP, Fu G, Zheng H and Zhang L (2019) Bias in downscaled rainfall characteristics. In Review.

Saft M, Peel MC, Western AW, Perraud JM and Zhang L (2016) Bias in streamflow projections due to climate-induced shifts in catchment response. Geophysical Research Letters, 43, 1574-1581.

Vaze J, Post DA, Chiew FHS, Perraud J-M, Viney N and Teng J (2010) Climate non-stationarity - validity of calibrated rainfall-runoff models for use in climate change studies. Journal of Hydrology, 394, 447-457.

Zhao RJ (1992) The Xinanjiang model application in China. Journal of Hydrology, 135, 371-381. 